personal friend and professional educator for more than two decades, states: "He exhibited a type of charisma seldom seen among us. He fostered love for all mankind without seeking or expecting a return."

In one of his last meetings with one of his classes, Professor Mazer shared with his students some of his profound thoughts about "What he would want us to be for one another in our efforts to live as God's people."

He wrote, in part:

We are created, not for isolation, but for relationships. At heart, we are not a thousand points of separated light but, rather, part of a larger brightness. To live is to reach out to others. 'People who need people are the luckiest people in the world,' a popular song tells us. That includes all of us. Initiating, developing, and maintaining caring and committed relations is the most important (and often the most underestimated) activity in our lives. From the moment we are born to the moment we die, relationships are the core of our existence. We are conceived within relationships. We are dependent on other people for the realization of life itself, for survival during one of the longest gestation periods in the animal kingdom, for food and shelter and aid and comfort throughout our lives, for the love and education necessary for our social and cognitive development, for guidance in learning the essential competencies required to survive in our world, and for fun, excitement, comfort, love, personal confirmation, and fulfillment. Our relationships with others form the context for all other aspects of our lives.

This was life as Stanley Mazer lived it. His example will be greatly missedbut will hopefully serve as a model for young scholars.

Jewel L. Prestage Southern University

\section{Wilma L. Rule}

Wilma L. Rule, adjunct professor, University of Nevada, Reno, died on January 15, 2004 at her home in Alpine County, California of a massive stroke. She was a dedicated scholar whose focus was gender and politics with particular interest in electoral systems.

Wilma was born on September 19, 1925 in a ranching family in Basin, Wyoming, but was reared in Los Angeles. She received a B.A. in Political Science and in Journalism in 1949 and an M.A. in Political Science in 1950, from the University of California at Berkeley. Her Ph.D. was granted by the University of Hawaii in 1968. She was awarded a post-doctoral fellowship for the Inter-University Consortium for Political Research at the University of Michigan, and did additional postdoctoral work in Organizational Behavior at Northwestern University. She was an assistant professor at Northern Illinois University 1969-1975.

Her study of gender and politics, published in the American Political Science Review ("Political Implications of Gender Roles: A Review of the Literature," 1974) led to a lifetime of research on electoral systems, and how they facilitated or hindered the election of women and underrepresented minorities to public office. Her theoretical work had a practical dimension: the promotion of electoral reform in the United States and other nations. Her theoretical interest was underpinned by empirical research, prompted by her questioning why, at the time, there were only $5 \%$ women legislators in the U.S. House and Senate, compared to close to $40 \%$ in Scandinavian countries.

This led to an initial journey to Finland to interview women legislators, which set the pattern for subsequent research trips to other countries, including Norway and Russia.

Wilma's research resulted in a number of articles and the publication of United States Electoral Systems (1992) and Electoral Systems in Comparative Perspective (1994), both co-edited with Professor Joseph F. Zimmerman of State University of New York at Albany. Wilma's interviews of Russian legislators and political leaders was the basis of Russian Women in Politics and Society (1996), co-edited with Professor Norma C. Noonan of Augsburg College, Minnesota. These were followed by The U.S. House of Representatives, Reform or Rebuild? also co-edited with Professor Zimmerman. Wilma published some two dozen articles in professional journals, and presented over 25 papers at professional meetings in the United States and abroad. Work on her latest book, Equal Gender Politics: 21st Century, was cut short by her death.

Her work is highly respected by specialists in electoral reform. She served as a long-time Secretary-Treasurer of the Section on Representation and Electoral Systems of the American Political Science Association.

Wilma was married to Professor Irving Krauss, a sociologist, and they had endless discussions of whether that discipline or political science was better in understanding what went on in society. They lived 10 years in Hawaii, followed by 16 in Illinois, and, upon retirement, in Alpine County, on the eastern slope of the Sierra Nevada mountains. She is survived by Irving and several cousins.

Besides her scholarly work, Wilma was active in local politics, and in Hawaii played a major role in the election to the U.S. House of Representatives of Patsy Mink, co-author of Title Nine of the Education Act Ammendment of 1972, which mandated equal funding of men's and women's athletics in educational institutions. In Alpine County she was active in community affairs, and served as a member of the county's 1991 Redistricting Committee. In that capacity she was responsible for establishing a separate voting district for the county's Native Americans, which resulted in a seat on the Board of Supervisors as well as on the School Board. Prior to that, even though the Native Americans comprised $20 \%$ of the population, and were concentrated geographically, they lacked representation.

A good part of her work and achievements took place while she suffered from serious health problems. Yet she had a zest for living, and her professional colleagues and members of her community will miss her inquiring mind, her gentle nature, and her concern for others.

\section{Irving Krauss \\ Professor of Sociology Emeritus Northern Illinois University}

\section{Kurt Steiner}

Kurt Steiner, a political science professor emeritus known on campus as "Mr. Austria" who also helped draft Japan's postwar constitution, died at his home on campus Oct. 20, 2003. He was 91 .

Kurt Steiner was born June 10, 1912, in Vienna, Austria. He earned a law degree from the University of Vienna in 1935 and immigrated to the United States in 1938 after the Nazis seized power in Austria. In 1972, Steiner told the Stanford Daily that he fled his homeland because he knew that being Jewish, a lawyer, and an author of antiNazi magazine articles would have "assured my place in a concentration camp."

Clyde Steiner said his cousin lived with his family in Brooklyn after he came to the United States. "He was an old-world gentleman," Steiner recalled. "He was very much a dandy; he wore spats." As a newcomer, Kurt Steiner 
held a variety of jobs. "I came home one day and he was dressed as [an] ice cream man in a pink-and-white striped uniform," Steiner recalled, laughing. "It was an astounding change from this elegant man. He told me he would play a Bach cantata on the ice cream bells."

Steiner's wife-to-be, Kitty, whom he met in Austria in 1930, immigrated in 1939. The couple married and settled in Cleveland, Ohio.

Steiner, an accomplished linguist, headed Berlitz language schools in Cleveland and Pittsburgh until he joined the U.S. Army in 1944. He studied Japanese at the U.S. Military Intelligence School at Fort Snelling, Minnesota.

Steiner served in the Far Eastern war zone and the military government in Tokyo. "There, his foundation in European continental law and his linguistic skills positioned him uniquely for his work in the war crime trials," his cousin said. In 1948 and 1949, Steiner served as a prosecutor of major war criminals during trials in Japan.

"Prior to his court service, he was chief of documentary evidence collection for the tribunal," his cousin said. "This was a key role because the Japanese wartime leaders had destroyed Japanese records and the court had to rely on captured German documentation." A 400-page history of the trials of 25 major Japanese wartime criminals, based on Steiner's firsthand experiences, is expected to be published posthumously.

Kurt Steiner remained in Japan until 1951, serving as chief of civil affairs and civil liberties under General Douglas MacArthur and working with Japan's Diet to write its postwar constitution. "Under his direction, sweeping equality provisions were written into the constitution, overriding all previous law based on a 1,000-year-old feudal code, [which] had granted supreme power to individual family patriarchs," Clyde Steiner said.

After leaving Japan, Kurt Steiner came to Stanford to pursue graduate studies and work as a teaching assistant. He earned a doctorate from Stanford in political science in 1955 and that year joined the faculty, teaching comparative politics and the politics of Japan. He retired in 1977.

In 1958, Steiner was a founding faculty member of Stanford's first overseas study center near Stuttgart, Germany, and in 1965 he helped open the university's campus in Semmering, Austria. The program moved in 1968 to Vienna, where it remained until it closed in the mid-1980s. In 1977, the Austrian govern- ment endowed Stanford with a visiting professorship in Austrian studies. Steiner chaired the advisory committee for that professorship for more than a decade.

Steiner wrote Local Government in Japan (1965); Politics in Austria (1972); and Political Opposition and Local Politics in Japan (1979). In 1981, he edited Modern Austria, one of the few works of its kind in English.

At the time, then political science Professor Robert Ward told Stanford News Service that Steiner was "one of the few people who writes professionally on Austria [in English]. He is one of the better known ex-Austrians in the U.S." A biography of Steiner, entitled Between the Worlds, was published in Austria in 2002 and is being translated into English.

Steiner received numerous medals from the Austrian government and the city of Vienna for his work. In 1990, the University of Vienna awarded him an honorary doctorate in social and economic sciences.

The Steiners had no children. Steiner is survived by two relatives, Clyde of San Francisco and Grace Davis of Palo Alto.

Lisa Trei Stanford University News Service 